\title{
Effect of Tillage and Nutrient Management Practices on Maydis Leaf Blight of Maize
}

\author{
Bhuwan Chandra Sharma ${ }^{*}$, Rajesh Pratap Singh ${ }^{2}$ and Amit Bhatnagar ${ }^{3}$ \\ ${ }^{1}$ Department of Plant Pathology, ${ }^{2}$ Department of Agronomy, Collage of Agriculture, Govind \\ Ballabh Pant University of Agriculture \& Technology, Pantnagar, Udham Singh Nagar, \\ Uttarakhand, India \\ *Corresponding author
}

\section{A B S T R A C T}

\section{Keywords}

A Maydis leaf blight, Tillage management, Nutrient management, Integrated management

\section{Article Info}

Accepted: 28 August 2020 Available Online: 10 September 2020

\begin{abstract}
Maydis leaf blight caused by Biopolaris maydis is highly destructive diseases of maize crop worldwide including India. Depending upon weather conditions they cause the significant yield reduction ranging from 28 to $91 \%$ in maize crop. Hot and humid conditions preferred by Maydis leaf blight. It is present in all tropical and temperate maize growing regions. Growing conditions creating hot and humid condition are most advantageous for the development of the disease. Under tarai condition of Uttrakhand an experiment was carried out by integrating tillage practices like - permanent raised beds, zero tillage and conventional tillage along with different nutrient management approaches like- RDF, SSNF and Farmer's practices for the management of maize diseases. Results of present study indicated that conventional tillage followed by permanent raised bed and zero tillage and in nutrient management SSNM followed by RDF management practices were found equally good with respect to disease severity but significantly higher grain yield was recorded in permanent raised beds $(5817 \mathrm{Kg} / \mathrm{ha})$ and in conventional tillage $(5748 \mathrm{Kg} / \mathrm{ha})$ which was found at par with permanent raised beds whereas minimum yield was recorded in zero tillage $(5617 \mathrm{Kg} / \mathrm{ha}$ ). But significantly higher thousand grain weight was recorded in conventional tillage (306 g) and permanent beds (305 g) which was at par, followed by zero tillage $(282 \mathrm{~g})$.
\end{abstract}

\section{Introduction}

Where ever maize is grown Maydis leaf blight (MLB) disease is almost present. It is also known as Southern corn leaf blight (SCLB) and caused by fungus Bipolaris maydis (Y. Nisik. \& C. Miyake) Shoemaker, (Teleomorph: Cochliobolus heterostrophus (Drechsler) Drechsler. Under hot and humid, tropical and temperate climates of the world the disease is highly destructive. First time from United States Drechsler reported the fungus Helminthosporium maydis in 1925. Munjal and Kapoor (1960) was first time reported $H$. maydis from Maldah district in West Bengal, (India), The outbreak of Helminthosporium maydis from Ludhiana and Rajasthan reported by Sharma et al., (1978). In Andhra Pradesh, Bihar, Delhi, Gujarat, Haryana, Himachal Pradesh, Jammu \& 
Kashmir, Karnataka, Madhya Pradesh, Maharashtra, Meghalaya, Punjab, Rajasthan, Sikkim, Tamil Nadu Uttarakhand and Uttar Pradesh states of India now Helminthosporium maydis has become a serious problem. Under different weather conditions Maydis Leaf Blght causes yield reduction ranging from 28 to $91 \%$ in maize crop (Bera and Giri, 1979; Harlapur et al., 2000; Sharma et al., 2003; Sharma and Sharma, 2006; Sharma and Singh 2019; Kumar and Saxena, 2007). Wang et al., (2001) and Ali et al., (2011) have reported yield loss up to the extent of 70 percent Due to this disease. Sumner and Littrell (1974) reported that survival and spread of disease depends upon amount of rainfall, relative humidity and temperature of the area. Schenck and Stelter (1974) reported that long and sunny growing seasons with dry conditions are highly unfavorable for disease development. High humidity level and a warm temperatures range between $20^{\circ} \mathrm{C}$ to $32^{\circ} \mathrm{C}$ are particularly conducive to MLB (Anonymous, 1997). Ullstrup (1972) reported that pathogen can not survive in debris buried at $5-20 \mathrm{~cm}$ but it can survive in infected maize debris on the soil surface or in seed. The MLB pathogen found on seed and it spreads on seedlings from infected seeds (Boothryod, 1971; Kulik, 1971; Singh et al., 1974). Under in vitro condition nearly $28^{\circ} \mathrm{C}$ is Optimum temperature for growth and conidial germination. The temperature range of 20$28^{\circ} \mathrm{C}$ is needed for conidial sporulation under continuous light and $28^{\circ} \mathrm{C}$ in total dark for race $\mathrm{O}$, while for race $\mathrm{T}$ it is $20^{\circ} \mathrm{C}$ and $24^{\circ} \mathrm{C}$, respectively (Aylor, 1975).

Cultivation practices favoring high humidity and moderate temperature conditions may influence the development of maydis blight. Keeping in view the importance of this disease in the region an integrated strategy involving tillage practices and nutrient management practices like Recommended
Dose of fertilizers, Site Specific Nutrient Management and Farmer's practices were evaluated for devising an integrated approach for the management of Maydis leaf blight of maize under tarai conditions of Uttarakhand.

\section{Materials and Methods}

Field experiment was conducted during kharif 2017 and 2018 in Maize Agronomy block at Norman E. Borlaug Crop Research Centre, G.B. Pant University of Agriculture and Technology, Pantnagar, Udham Singh Nagar, Uttarakhand. It has sub tropical climate with hot and humid summer and cold winters. Field experiments were conducted using hybrid DH 296 to develop the integration of tillage and nutrient management practice for the management of maydis leaf blight of maize. Plot size was 3.0 meter $\times 4.00 \mathrm{~m}^{2}$ with three replication of each treatment. Trail was laid out in split plot design with three types of tillage practices viz, Permanent Raised Beds (PRB), Zero tillage (ZT) and Conventional tillage (CT) as in main plot and three sub plot viz, Recommended Dose of fertilizers (RDF), Site Specific Nutrient Management (SSNM) and Farmer's practices (FP). The spacing was $60 \mathrm{~cm} \times 25 \mathrm{~cm}$. There were 5 rows in each plot. Permanent bed and zero tillage treatment were initiated in year 2012. Permanent bed were made at $60 \mathrm{~cm}$ with the help of tractor drawn FIRBS. These permanent beds were reshaped every year before sowing of maize. In permanent beds and zero tillage sowing was done manually. In conventional tillage there were four harrowing fallowed by leveling and sowing was done by tractor drown furrow opener. Recommended dose of nutrient was 120: 60: $40 \mathrm{~N}: \mathrm{P}_{2} \mathrm{O}_{5}: \mathrm{K}_{2} \mathrm{O} \mathrm{kg} / \mathrm{ha}$. In farmer practices, their thirty maize growing farmers were selected and their nutrient dose was used for farmer's practices treatment. This was 93: 64: 32N: $\mathrm{P}_{2} \mathrm{O}_{5}: \mathrm{K}_{2} \mathrm{O} \mathrm{kg} / \mathrm{ha}$. In Site specific nutrient management nutrient dose was calculated by a computer software 
programme developed by International Plant Nutrition Institute in India (Majumdar et al., 2013) was 120: 30: $46 \mathrm{~N}: \mathrm{P}_{2} \mathrm{O}_{5}: \mathrm{K}_{2} \mathrm{O} \mathrm{kg} / \mathrm{ha}$. In year 2017 crop was sown on $19^{\text {th }}$ July and harvested on $2^{\text {nd }}$ November while in 2018 sowing was done on $19^{\text {th }}$ July and harvested on $29^{\text {th }}$ October. Plots were hand weeded with the help of hoe regularly. Observations on disease severity were recorded at 40, 55, 70 and 85 days after sowing using 1-9 rating scale (Hooda et al., 2018). Per cent diseases
Index (PDI) was calculate using formula given by Wheeler (1969).

$$
\mathrm{PDI}=\frac{\text { Sum of all disese ratings }}{\text { Total no. of observation } \mathrm{x} \text { Highest disease ratting scale }} \times 100
$$

Data was statistically analyzed using online programme "OPSTAT" a Statistical Software Package for Agricultural Research Workers developed by Sheoran et al., (1998).

Maydis leaf blight (MLB) rating scale (Hooda et al., 2018).

\begin{tabular}{|c|c|c|}
\hline Scale & Degree of infection & Diseased leaf area $(\%)$ \\
\hline 1.0 & Nil to very slight infection & $\leq 10 \%$ \\
\hline 2.0 & Slight infection, a few lesions scattered on two lower leaves & $10.1-20 \%$ \\
\hline 3.0 & $\begin{array}{l}\text { Light infection, moderate number of lesions scattered on four } \\
\text { lower leaves }\end{array}$ & $20.1-30 \%$ \\
\hline 4.0 & $\begin{array}{l}\text { Light infection, moderate number of lesions scattered on } \\
\text { lower leaves, a few lesions scattered on middle leaves below } \\
\text { the cob }\end{array}$ & $30.1-40 \%$ \\
\hline 5.0 & $\begin{array}{c}\text { Moderate infection, abundant number of lesions scattered on } \\
\text { lower leaves, moderate number of lesions scattered on } \\
\text { middle leaves below the cob }\end{array}$ & $40.1-50 \%$ \\
\hline 6.0 & $\begin{array}{l}\text { Heavy infection, abundant number of lesions scattered on } \\
\text { lower leaves, moderate infection on middle leaves and a few } \\
\text { lesions on two leaves above the cob }\end{array}$ & $50.1-60 \%$ \\
\hline 7.0 & $\begin{array}{l}\text { Heavy infection, abundant number of lesions scattered on } \\
\text { lower and middle leaves and moderate number of lesions on } \\
\text { two to four leaves above the cob }\end{array}$ & $60.1-70 \%$ \\
\hline 8.0 & $\begin{array}{l}\text { Very heavy infection, lesions abundant scattered on lower } \\
\text { and middle leaves and spreading up to the flag leaf }\end{array}$ & $70.1-80 \%$ \\
\hline 9.0 & $\begin{array}{l}\text { Very heavy infection, lesions abundant scattered on almost } \\
\text { all the leaves, plant prematurely dried and killed }\end{array}$ & $>80 \%$ \\
\hline
\end{tabular}

\section{Results and Discussion}

\section{Effect of tillage practices on severity of maydis leaf blight}

Disease severity measured in terms of Percent Disease Index (PDI) at different interval showed that different tillage practices taken as main plot and different nutrient management practices as sub plots were significantly different but their interaction was found statistically significant (Table 1).

Effect of different tillage practices on Maydis leaf blight after 40 days of sowing, in the year 2017 was significantly lower in conventional tillage $(14.57 \%$ ) followed by permanent beds (16.54\%) and zero tillage (18.77\%). Similar trend was observed in 2018 and significantly lower disease severity was recorded in 
conventional tillage $(15.31 \%)$ followed by permanent beds $(17.38 \%)$ and zero tillage (20.00\%). Similarly on pooled basis also lower severity was recorded in conventional tillage $(14.94 \%)$ followed by permanent beds $(16.96 \%)$ and zero tillage $(19.38 \%)$.

Significantly lower severity of Maydis leaf blight were recorded in Conventional tillage (16.54\%) followed by permanent beds (19.51 $\%)$ and zero tillage (22.72 \%) after 55 days of sowing, in the year 2017. Similar trend was found on pooled basis where lower severity was recorded in conventional tillage (16.91 $\%)$ followed by permanent beds (20.49\%), and Zero tillage (23.95\%), while in 2018 significantly lower severity was observed in conventional tillage (17.29\%) and permanent beds $(21.48 \%)$ followed by zero tillage $(25.19 \%)$.

During the year 2017, 2018 and on pooled basis after 70 days of sowing significantly lower severity of Maydis leaf blight was recorded in conventional tillage with 22.22 , $23.46,22.84$ followed by permanent beds 25.68, 27.41, 26.54 and zero tillage 28.39, 30.37, 29.38 percent, respectively. After 85 days of sowing significantly lower severity was observed in conventional tillage with 28.39, 27.90, 28.15 followed by permanent beds $31.85,31.85,31.85 \%$ and zero tillage $36.30,36.05,36.17$ percent, respectively.

\section{Effect of nutrient management on severity of Maydis leaf blight of maize}

After 40 days of sowing in year 2017 lower severity of Maydis leaf blight was noticed in Site specific nutrient management $(13.58 \%)$ and Recommended dose of fertilizer (17.04 $\%$ ) which was at par, followed by Farmers practices (19.26\%) while, in 2018 lower severity of Maydis leaf blight was recorded in SSNM (14.32 \%) followed by RDF (17.88 \%) and FP (20.49\%). Similarly on pooled basis lower severity was observed in SSNM (13.95 $\%$ ) followed by RDF (17.46 \%) and FP (19.88 $\%)$.

During the year 2017, 2018 and on pooled basis after 55 days of sowing significantly lower severity of Maydis leaf blight was recorded in SSNM (15.80, 16.79, $16.30 \%)$ followed by RDF (20.49, $22.4721 .48 \%$ ) and FP (22.47, 24.69, 23.58 percent, respectively). Similar trend was found at 70 days after sowing where significantly lower severity of Maydis leaf blight was observed in SSNM (20.49, 21.24, 20.87\%) followed by RDF (26.67, 28.64, $27.66 \%)$ and FP 29.14, 31.36 and 30.25 percent, respectively).

After 85 days of sowing in the year 2017 significantly lower severity of Maydis leaf blight was recorded in SSNM (25.93 \%) followed by RDF (33.58 \%) and FP (37.04 \%) while in year 2018 also significantly lower severity was recorded in SSNM (25.68 \%) followed by RDF (33.58 \%) and FP (36.54 $\%)$. Similar trend was observed on pooled basis where significantly lower severity (25.80 \%) was recorded in SSNM followed by $\operatorname{RDF}(33.58 \%)$ and FP $(36.79 \%)$.

\section{Effect of tillage and nutrient management practices on yield}

The data on yield parameters of maize as influenced by different Tillage practice have been shown in Table 2 In year 2017 and on pooled basis no significant difference was found in grain yield as well as thousand grain weight whereas in the year 2018 significantly higher grain yield was recorded in permanent beds (5.817 t/ha) which was found at par with conventional tillage (5.748 t/ha) whereas minimum yield was recorded in zero tillage (5.617 t/ha). In year 2018 significantly higher thousand grain weight was recorded in conventional tillage (306 g) which was at par with permanent beds (305 g), followed by zero tillage ( $282 \mathrm{~g})$. 
Table.1 Effect of tillage practices and nutrition management on severity (PDI) of Maydis leaf blight

\begin{tabular}{|c|c|c|c|c|c|c|c|c|c|c|c|c|c|}
\hline \multirow{2}{*}{$\begin{array}{c}\text { Main Plot } \\
\text { Tillage } \\
\text { practices }\end{array}$} & \multirow{2}{*}{$\begin{array}{c}\text { Sub plot } \\
\text { Nutrition management }\end{array}$} & \multicolumn{3}{|c|}{40 DAS } & \multicolumn{3}{|c|}{55 DAS } & \multicolumn{3}{|c|}{70 DAS } & \multicolumn{3}{|c|}{85 DAS } \\
\hline & & 2017 & 2018 & Pooled & 2017 & 2018 & Pooled & 2017 & 2018 & Pooled & 2017 & 2018 & Pooled \\
\hline \multirow[t]{3}{*}{$\begin{array}{l}\text { Permanent } \\
\text { beds }\end{array}$} & $\begin{array}{l}\text { Recommended dose of } \\
\text { fertilizer }\end{array}$ & 17.04 & 18.08 & 17.56 & 20.74 & 22.96 & 21.85 & 27.41 & 29.63 & 28.52 & 33.34 & 34.08 & 33.71 \\
\hline & Farmer's practice & 19.26 & 20.00 & 19.63 & 22.22 & 25.18 & 23.70 & 28.89 & 31.11 & 30.00 & 37.04 & 35.56 & 36.30 \\
\hline & $\begin{array}{l}\text { Site Specific nutrient } \\
\text { management }\end{array}$ & 13.33 & 14.07 & 13.70 & 15.56 & 16.30 & 15.93 & 20.74 & 21.48 & 21.11 & 25.18 & 25.92 & 25.55 \\
\hline \multirow[t]{3}{*}{$\begin{array}{c}\text { Conventional } \\
\text { tillage }\end{array}$} & $\begin{array}{l}\text { Recommended dose of } \\
\text { fertilizer }\end{array}$ & 14.82 & 15.56 & 15.19 & 17.04 & 17.78 & 17.41 & 22.96 & 24.45 & 23.71 & 29.63 & 28.89 & 29.26 \\
\hline & Farmers practice & 17.04 & 17.78 & 17.41 & 19.26 & 20.00 & 19.63 & 25.93 & 28.15 & 27.04 & 32.59 & 32.59 & 32.59 \\
\hline & $\begin{array}{l}\text { Site Specific nutrient } \\
\text { management }\end{array}$ & 11.85 & 12.59 & 12.22 & 13.33 & 14.08 & 13.70 & 17.78 & 17.78 & 17.78 & 22.96 & 22.22 & 22.59 \\
\hline \multirow[t]{3}{*}{ Zero tillage } & $\begin{array}{l}\text { Recommended dose of } \\
\text { fertilizer }\end{array}$ & 19.26 & 20.00 & 19.63 & 23.70 & 26.67 & 25.19 & 29.63 & 31.85 & 30.74 & 37.78 & 37.78 & 37.78 \\
\hline & Farmers practice & 21.48 & 23.70 & 22.59 & 25.93 & 28.89 & 27.41 & 32.59 & 34.82 & 33.70 & 41.48 & 41.48 & 41.48 \\
\hline & $\begin{array}{l}\text { Site Specific nutrient } \\
\text { management }\end{array}$ & 15.56 & 16.30 & 15.93 & 18.52 & 20.00 & 19.26 & 22.96 & 24.44 & 23.70 & 29.63 & 28.89 & 29.26 \\
\hline \multicolumn{14}{|c|}{ Tillage } \\
\hline \multicolumn{2}{|c|}{ Permanent beds } & 16.54 & 17.38 & 16.96 & 19.51 & 21.48 & 20.49 & 25.68 & 27.41 & 26.54 & 31.85 & 31.85 & 31.85 \\
\hline \multicolumn{2}{|c|}{ Conventional tillage } & 14.57 & 15.31 & 14.94 & 16.54 & 17.29 & 16.91 & 22.22 & 23.46 & 22.84 & 28.39 & 27.90 & 28.15 \\
\hline \multicolumn{2}{|c|}{ Zero tillage } & 18.77 & 20.00 & 19.38 & 22.72 & 25.19 & 23.95 & 28.39 & 30.37 & 29.38 & 36.30 & 36.05 & 36.17 \\
\hline \multicolumn{2}{|c|}{ SE $(\mathrm{m})$} & 0.14 & 0.43 & 0.24 & 0.22 & 0.38 & 0.30 & 0.25 & 0.38 & 0.30 & 0.14 & 0.33 & 0.19 \\
\hline \multicolumn{2}{|r|}{ CD@5\% } & 0.58 & 1.72 & 0.98 & 0.91 & 1.52 & 1.20 & 1.00 & 1.52 & 1.20 & 0.58 & 1.35 & 0.76 \\
\hline \multicolumn{14}{|c|}{ Nutrition } \\
\hline \multicolumn{2}{|c|}{ Recommended dose of fertilizer } & 17.04 & 17.88 & 17.46 & 20.49 & 22.47 & 21.48 & 26.67 & 28.64 & 27.66 & 33.58 & 33.58 & 33.58 \\
\hline \multicolumn{2}{|c|}{ Farmer's practice } & 19.26 & 20.49 & 19.88 & 22.47 & 24.69 & 23.58 & 29.14 & 31.36 & 30.25 & 37.04 & 36.54 & 36.79 \\
\hline \multicolumn{2}{|c|}{ Site Specific nutrient management } & 13.58 & 14.32 & 13.95 & 15.80 & 16.79 & 16.30 & 20.49 & 21.24 & 20.87 & 25.93 & 25.68 & 25.80 \\
\hline \multicolumn{2}{|c|}{$\mathrm{SE}(\mathrm{m})$} & 0.61 & 1.04 & 0.81 & 0.72 & 0.98 & 0.83 & 0.84 & 1.03 & 0.93 & 1.04 & 1.08 & 1.05 \\
\hline \multicolumn{2}{|r|}{ CD@5\% } & 1.89 & 3.23 & 2.52 & 2.24 & 3.06 & 2.59 & 2.63 & 3.20 & 2.90 & 3.25 & 3.37 & 3.26 \\
\hline
\end{tabular}

*DAS- Days after sowing 
Table.2 Effect of tillage practices and nutrition management on yield

\begin{tabular}{|c|c|c|c|c|c|c|c|}
\hline \multirow{2}{*}{$\begin{array}{c}\text { Main Plot } \\
\text { Tillage practices }\end{array}$} & \multirow{2}{*}{$\begin{array}{c}\text { Sub plot } \\
\text { Nutrition management }\end{array}$} & \multicolumn{3}{|c|}{ Grain yield (t/ha) } & \multicolumn{3}{|c|}{1000 Grain weight (g) } \\
\hline & & 2017 & 2018 & Pooled & 2017 & 2018 & Pooled \\
\hline \multirow[t]{3}{*}{ Permanent beds } & Recommended dose of fertilizer & 6.097 & 5.361 & 5.729 & 288 & 302 & 295 \\
\hline & Farmer's practice & 5.350 & 5.049 & 5.200 & 280 & 309 & 295 \\
\hline & Site Specific nutrient management & 6.004 & 5.136 & 5.570 & 286 & 305 & 296 \\
\hline \multirow[t]{3}{*}{ Conventional tillage } & Recommended dose of fertilizer & 5.992 & 5.521 & 5.756 & 282 & 309 & 295 \\
\hline & Farmers practice & 5.312 & 5.029 & 5.171 & 280 & 306 & 293 \\
\hline & Site Specific nutrient management & 5.939 & 5.196 & 5.568 & 290 & 303 & 297 \\
\hline \multirow[t]{3}{*}{ Zero tillage } & Recommended dose of fertilizer & 5.929 & 4.649 & 5.289 & 289 & 280 & 284 \\
\hline & Farmers practice & 5.149 & 4.327 & 4.739 & 283 & 282 & 283 \\
\hline & Site Specific nutrient management & 5.774 & 4.471 & 5.123 & 284 & 284 & 285 \\
\hline \multicolumn{8}{|c|}{ Tillage } \\
\hline \multicolumn{2}{|c|}{ Permanent beds } & 5.817 & 5.182 & 5.500 & 285 & 305 & 295 \\
\hline \multicolumn{2}{|c|}{ Conventional tillage } & 5.748 & 5.249 & 5.498 & 284 & 306 & 295 \\
\hline \multicolumn{2}{|c|}{ Zero tillage } & 5.617 & 4.482 & 5.050 & 285 & 282 & 284 \\
\hline \multicolumn{2}{|r|}{ SE(m) } & 0.144 & 0.107 & 0.118 & 3 & 4 & 3 \\
\hline \multicolumn{2}{|r|}{ CD@ $0 \%$} & NS & 0.432 & NS & NS & 16 & NS \\
\hline \multicolumn{8}{|c|}{ Nutrition } \\
\hline \multicolumn{2}{|c|}{ Recommended dose of fertilizer } & 6.006 & 5.177 & 5.591 & 286 & 297 & 292 \\
\hline \multicolumn{2}{|c|}{ Farmer's practice } & 5.271 & 4.802 & 5.036 & 281 & 299 & 290 \\
\hline \multicolumn{2}{|c|}{ Site Specific nutrient management } & 5.905 & 4.935 & 5.420 & 287 & 297 & 292 \\
\hline \multicolumn{2}{|c|}{ SE $(\mathbf{m})$} & 0.144 & 0.229 & 0.111 & 4 & 5 & 3 \\
\hline \multicolumn{2}{|r|}{ CD@ $9 \%$} & 0.448 & NS & 0.345 & NS & NS & NS \\
\hline
\end{tabular}


After comparing various tillage practices it is cleare that conventional tillage practices gave maximum grain yield, followed by minimum tillage and zero tillage. These results are supported by findings of Khurshid et al., (2006) and Khan et al., (2001) elucidated that1000-grain weight of maize significantly increased in conventional till plots rather than no tilled plots.

Nutrient management significantly influence grain yield (Table 2). Grain yield recorded in RDF (6.006 t/ha) was at par with SSNM (5.905 t/ha) followed by FP (5.271 t/ha). In year 2018 no significant difference was found in grain yield. On pooled basis significantly higher grain yield was recorded in RDF (5.591 t/ha) which was found with at par SSNM (5.420 t/ha), followed by FP (5.036 t/ha). In year 2017, 2018 and on pooled basis no significant difference was found on thousand grains weight.

The higher grain yield of maize was mainly due to SSNM approach was ascribed due to higher but balanced nutrient application. This was evident through the findings of Jayaprakash et al., (2006), Kumar et al., (2007) and Umesh (2008) who reported higher grain yield of maize with application of SSNM and STCR.

No significant difference was found on thousand grain weight due to nutrition management. The result confirms the findings of Sharar et al., 2003, who reported that the yield attributes increased with increased levels of fertilizer. While, Sivamurugan et al., (2017) reported that RDF registered the highest 100 seed weight and it was comparable with STCR but superior to SSNM.

In conclusion the results of present study indicated that conventional tillage practice integrated with Site specific nutrient management were found good with respect to minimize the severity of maydis leaf blight but permanent raised beds and recommended dose of fertilizer provided higher yield than conventional tillage and site specific nutrient management which was at par. Zero tillage and farmer's practice was found least effective with respect to disease severity and yield.

\section{Acknowledgement}

Support provided by Directorate of Research of GBPUAT, Pantnagar and AICRIP on Maize for conducting the field experiment is duly acknowledged.

\section{References}

Ali, F., Muneer, M., Rahman, H., Noor, M., Durrishahwar, Shaukat, S. and Yan, J.B. (2011). Heritability estimates for yield and related traits based on testcross progeny performance of resistant maize inbred lines. Journal of Food, Agriculture and Environment, 9: 438443.

Anonymous (1997). Common Leaf Blights and Spots of Corn. University of Illinois Extension, Urbana-Champaign.

Aylor, D. E. (1975). Force required detaching conidia of Helminthosporium maydis. Plant Physiology, 55: 99-101.

Bera, A.K. and Giri, D.N. (1979). Occurrence of southern corn leaf blight in India. Plant Disease Reporter, 63(5): 419.

Boothroyd, C.W. (1971). Transmission of Helminthosporium maydis race $\mathrm{T}$ by infected corn seed. Phytopathology, 61: 747-48.

Drechsler, C. (1925). Leaf spot of maize caused Ophiobolus hetrostrophus, the asciogerous stage of Helminthosporium exhibiting bipolar germination. Journal of Agricultural Research, 31: 701-726.

Harlapur, S.I., Mruthunjaya, C.W., Anahosur, 
K.H. and Muralikrishna, S. (2000). A report survey and surveillance of maize diseases in North Karnataka. Karnataka Journal of Agricultural Sciences, 13(3): 750-751.

Hooda, K.S.; Bagaria, P.K.; Khokhar, Mukesh; Kaur, Harleen and Rakshit, Sujay. (2018). Mass Screening Techniques for Resistance to Maize Diseases. ICAR-Indian Institute of Maize Research, PAU Campus, Ludhiana- 141004, 93pp.

Jayaprakash, T. C.; Nagalikar, V. P.; Pujari, B. T. and Setty, R. A. 2006. Effect of organics and inorganics on growth and yield of maize under irrigation. Karnataka Journal Agriculture Science, 18(3): 798.

Khan, F.U.H.; A.R. Tahir and I.J Yule. 2001. Intrinsic implication of different tillage practices on soil penetration resistance and crop growth. International Journal of Agricultural Biology, 1: 6-23.

Khurshid, K., M.; Iqbal, Arif M.S. and Nawaz A. 2006. Effect of tillage and mulch on soil physical properties and growth of maize. International Journal of Agricultural Biology, 8: 593-596.

Kulik, M.M. (1971). A blotter method for detecting seed bore Drechslera maydis, the incitant of southern leaf blight of corn. Proc. Associations Official Seed Analysis 61: 119-22.

Kumar, A.; Gali, S. K. and Hebsur, S. 2007. Effect of different levels of NPK on growth and yield parameters of sweet corn. Karnataka Journal of Agricultural Sciences, 20 (1): 41-43.

Kumar, P. and Saxena, P. (2007). Prevalence of southern leaf blight of maize in Jhansi and its surroundings. Flora and Fauna Jhansi, 13(1): 33-36.

Majumdar K.; Satyanarayana T.; Pampolino M.; Dutta S.; Jat M.L.; Sulewski G. and Johnston A.M. 2013. Nutrient Expert ® for Hybrid Maize (version 1.1). A decision support tool for providing field specific fertilizer recommendations for tropical hybrid maize. International Plant Nutrition Institute and International Maize and Wheat Improvement Center, India. Pp. 52.

Munjal, R. L. and Kapoor, J. N. (1960). Some unrecorded diseases of sorghum and maize from India. Currunt Science, 29: 442-443.

Schenck, N.C. and Stelter, T.J. (1974). Southern corn leaf blight development relative to temperature, moisture and fungicide applications. Phytopathology 64: 619-24.

Sharar, M. S.; Ayub, M.; Nadeem M. A. and Ahmad N. 2003.Effect of different rates of nitrogen and phosphorus on growth and grain yield of maize. Asian Journal of Plant Science, 2(3): 347-349

Sharma, B.C. \& Singh, R.P. (2019). Effect of Planting Methods and Management Practices on Maydis Leaf Blight of Maize. Indian Journal of Pure and Applied. Biosciences 7(5), 147-153. doi: http: //dx.doi.org/10.18782/23207051.7825

Sharma, R.C. and Sharma, S. (2006). Diseases of poplar in India and their management. Short rotation forestry for industrial and rural development, In: Proceedings of the International Conference on World Perspective on Short Rotation Forestry for Industrial and Rural Development, Nauni, Solan, India. pp. 364-370.

Sharma, R.C., Lilaramani, J. and Payak, M.M. (1978). Outbreak of a new pathotype of Helminthosporium maydis on maize in India. India Phytopathology, 31(1): 112113.

Sharma, R.C., Rai, S.N., Mukherjee, B.K. and Gupta, N.P. (2003). Assessing potential of resistance source for the enhancement of resistance to maydis leaf blight (Bipolaris maydis) in maize 
(Zea mays L.). Indian Journal of Genetics and Plant Breeding, 63(1): 3336.

Sheoran, O.P; Tonk, D.S; Kaushik, L.S; Hasija, R.C and Pannu, R.S (1998). Statistical Software Package for Agricultural Research Workers. Recent Advances in information theory, Statistics \& Computer Applications by D.S. Hooda \& R.C. Hasija Department of Mathematics Statistics, CCS HAU, Hisar, India. pp: 139-143.

Singh, D.V., Mathur, S.B. and Neergaard, P. (1974). Seed health testing of maize. Evaluation of testing techniques with special reference to Drechslera maydis. Seed Science Technology 2: 349-65.

Sivamurugan A. P.; Ravikesavan R. and Yuvaraja A. 2017. Effect of Planting Density and Nutrient Management Practices on the Performance of Maize Hybrids in Kharif Season. Chemical Science Review and Letters, ISSN
2278-6783.

Summer, D.R., and Littrell, R.H. (1974). Influence of tillage, planting date, inoculum survival and mixed population on epidemiology of southern com leaf blight. Phytopathology 64: 168-173.

Ullstrup, A.J. (1972). The impact of the southern corn leaf blight epidemics of 1970-71. Annual Review Phytopathology 10: 37-50.

Umesh, M. R. 2008, Investigation on balanced fertilization for maizepigeonpea cropping sequence in Alfisols of Karnataka. Ph.D.Thesis. Univ. Agric. Sci., Bangalore

Wang, X.M., Dai, F.C., liao, Q. and Sun, S.X. (2001). Field Corn Pest Manual. China Agricultural Science and Technology Publishing House, Beijing. pp. 4-102.

Wheeler, B.E.J. (1969). An introduction to plant disease, John Wiley and fungi. Phytopathology, 22: 837-845.

\section{How to cite this article:}

Bhuwan Chandra Sharma, Rajesh Pratap Singh and Amit Bhatnagar. 2020. Effect of Tillage and Nutrient Management Practices on Maydis Leaf Blight of Maize. Int.J.Curr.Microbiol.App.Sci. 9(09): 3735-3743. doi: https://doi.org/10.20546/ijcmas.2020.909.461 